Valentin Kravchenko, $\mathrm{PhD}$ in Engineering Science, Senior Lecturer, Department of Concrete Technology and Building Materials, Brest State Technical University (Brest, Belarus)

\title{
EARLY AGE RESTRAINED STRAINS AND SELF- STRESSES OF THE EXPANSIVE CONCRETE CORE IN THE SYMMETRICAL PLANE RESTRAINED CONDITION
}

(C) РУП “Институт БелНИИС", 2019

Institute BeINIIS RUE, 2019

\section{ABSTRACT}

The expansive concrete is used in the reinforced concrete structures to shrinkage compensating. Most efficiently its application in the Concrete Filled Steel Tubes (CFST), in which the expansive concrete can't only compensate basic shrinkage of the filled CFST to effectively prevent separation structure but also induce self-stresses in the concrete core to keep it under in-plane biaxial compression before applying load.

The practical design of the CFST structures requires accurate estimation of restrained strain and stress in the expansive concrete core during the early age of curing. Currently, phenomenological models for the estimation of concrete strains are commonly used. At the same time, there are models which based on the principles and assumptions of the elasticity theory that have advantages over phenomenological models. Major disadvantage of these models is that they consider the development of concrete strains, taking into account only its elastic behavior, which predetermines their low accuracy.

In this article, the stress-strain development model for the restrained expansion strains and self-stresses estimation of expansive concrete core, taking into account the relaxation stresses due elastic and plastic deformation under both internal (aggregate) and external (steel shell) restrained conditions and a cumulative force induced by these restrains, what allows to determine more accuracy values is presented. 
Keywords: cement paste, free expansion strains, restrained conditions, relaxation stresses, cumulative force, estimation model.

For citation: Kravchenko V. Early age restrained strains and self-stresses of the expansive concrete core in the symmetrical plane restrained condition. Contemporary Issues of Concrete and Reinforced Concrete: Collected Research Papers. Minsk. Institute BelNIIS. Vol. 11. 2019. pp. 36-50. https://doi.org/10.35579/2076-6033-2019-11-03

Кравченко Валентин Викторович, канА. техн. наук, старший препоАаватель, кафеАра технологии бетона и строительных материалов, Брестский государственный технический университет (г. Брест, Беларусь)

\section{СВЯЗАННЫЕ АЕФОРМАЦИИ И САМОНАПРЯЖЕНИЯ В РАННЕМ ВОЗРАСТЕ НАПРЯГАЮЩЕГО БЕТОНА В УСЛОВИЯХ ПАОСКОГО СИММЕТРИЧНОГО ОГРАНИЧЕНИЯ}

\section{АННОТАЦИЯ}

Напрягающий бетон используют в железобетонных конструкциях как один из способов компенсации усадочных деформаций бетона. Наиболее эффективно его применение в сталетрубобетонных элементах, в которых напрягающий бетон не только компенсирует усадку, предотвращая отделение стальной оболочки от бетонного ядра, но также способствует возникновению самонапряжений в бетонном ядре, сохраняя его двухосное обжатие до момента приложения нагрузки.

Для проектирования сталетрубобетонных элементов из напрягающего бетонанеобходима точная оценка развития собственных деформаций и самонапряжений бетонного ядра во времени. $B$ настоящее время в строительной практике для прогнозирования собственных деформаций бетона в основном используют феноменологические модели. В то же время существуют также модели, основанные на положениях и допущениях теории упругости, которые обладают рядом преимуществ перед феноменологическими 
моделями. Основным недостатком таких моделей является то, что они рассматривают развитие деформаций бетона, принимая во внимание только его упругое поведение, что в конечном итоге предопределяет их невысокую точность.

В данной статье предложена модель для оценки собственных связанных деформащий и самонапряжений в ядре из напрягающего бетонного в сталетрубобетонных элементах, которая учитывает релаксацию собственных напряжений в результате проявления упругой и пластической деформации в условиях внутреннего (заполнитель) и внешнего (стальная оболочка) ограничений, а также результирующее поле напряжений от суммарной реакции в ограничивающих связях, что позволяет получать более адекватные их значения.

Ключевые слова: цементный камень, свободные деформации расширения, ограничения, релаксация напряжений, результирующее усилие, расчетная модель.

Для цитирования: Кравченко, В. В. Связанные деформации и самонапряжения в раннем возрасте напрягающего бетона в условиях плоского симметричного ограничения / В. В. Кравченко / / Проблемы современного бетона и железобетона : сб. науч. тр. / Ин-т БелНИИС; редкол.: О. Н. Лешкевич [и др.]. - Минск, 2019. Вып. 11. - С. 36-50. https://doi.org/10.35579/2076-6033-2019-11-03

\section{INTRODUCTION}

In the reinforced concrete structures, the expansive concrete is used to shrinkage compensating, especially in case when high-strength concrete with low water-to-binder ratio or self-compacting concrete is applied. For this purpose, most efficiently application of expansive concrete in the Concrete Filled Steel Tubes (CFST). In the CFST structures expansive concrete can't only compensate basic shrinkage but also induces self-stresses in the concrete core.

So, expansive concrete is filled into steel tube to effectively prevent separation of the filled CFST structure which is often observed in a steel tube filled of the ordinary concrete, to keep the concrete core 
under in-plane biaxial compression before applying load, and avoid the premature buckling of the thin wall of the steel tube.

For the practical design of the CFST structures restrained strain and stress in the expansive concrete core during of the curing time, especially in the early age, should be estimated.

Currently, the most common approach for calculation of strain in expansive (ordinary) concrete consists of using the principle of superposition, that the total strain of concrete $\left(\varepsilon_{c}\right)$ is considered an algebraic sum of stress-induced strain $\left(\varepsilon_{\sigma}\right)$, free expansion (shrinkage) strain $\left(\varepsilon_{e}\right)$, and temperature strain $\left(\varepsilon_{t d}\right)$ :

$$
\varepsilon_{\tilde{n}}=\varepsilon_{\sigma}+\varepsilon_{e}+\varepsilon_{t d}
$$

Most of the existing models for prediction of the free expansion (shrinkage) strain of concrete involved in the Structural Codes are based on the phenomenological equations.

Some of the proposed models, that describes development of the free expansion (shrinkage) strain in time are based on the basic assumptions and principles of the Micromechanics of Composites (Elasticity Theory) with usage relation between cement paste expansion (shrinkage) and volume content of the aggregate (as an example is most common Pickett's model). The main advantage of such types of models consists in considering concrete as a composite in which free expansion strain actually creates in the cement paste under internal restrained conditions (aggregate). In case of CFST structures, the expansion strains also develop under external restrained conditions (steel shell).

Therefore, the term «restrained expansion strain» $\left(\varepsilon_{r e}\right)$ instead of the term «free expansion» is more suitable for describing concrete's expansive process since it always contains an internal restraint (aggregate).

However, models based of the mechanics of composite principles tend to over-predict free expansion (shrinkage) strain in time, because these models probably don't take into account: (a) stresses relaxation as a result of elastic and plastic strains under the restrained conditions, and (b) a cumulative force induced by the restraint that is considered 
as an additional applied load which restrict concrete expansion in accordance with [1].

In this article, the stress-strain development model for the restrained expansion strains and self-stresses estimation of expansive concrete core in the round steel tube under both internal (aggregate) and external (steel shell) restrained condition is presented.

\section{PROPOSED MODEL FOR PREDICTION OF THE RESTRAINED STRAIN AND SELF-STRESSES OF EXPANSIVE CONCRETE CORE IN THE CONCRETE FILLED STEEL TUBES}

The proposed model is based on the following main assumptions:

1. The microstructure of concrete is considered into two elementary heterogeneous levels:

- cement paste, as a combination of the products of hydration (CSH, unhydrated clinker phases, portlandite and aluminates) and porosity;

- concrete as a three-phase composite including a cement paste, aggregate grains, and an interfacial transition zone (ITZ).

2. The microstructure of concrete in each elementary level is isotropic, the development of strains and stresses for in all axes (directions) are the same.

3. The expansive concrete core is free from external applied loads.

4. In the proposed model, the development of restrained expansion strains is considered taking into account the relaxation of stresses as a result occur of elastic and plastic deformations.

5. The development of restrained expansion strains lead to occur forces in the restraints (both external and internal), which should be taking into account in equilibrium conditions as an additional stress field in the concrete core.

\section{Model formulation}

The basic equation for calculation of the incremental restrained expansion strain of concrete, in which a rigid aggregate restricts the free expansion of cement paste, can be presented as the following algebraic sum: 


$$
\left(\Delta \varepsilon_{\tilde{n} p}\right)_{i}=\left(\Delta \varepsilon_{i r}\right)_{i}+\left(\Delta \varepsilon_{e l}\right)_{i}+\left(\Delta \varepsilon_{p l}\right)_{i}
$$

where, $\left(\Delta \varepsilon_{c p}\right)_{i},\left(\Delta \varepsilon_{i r}\right)_{i},\left(\Delta \varepsilon_{e l}\right)_{i},\left(\Delta \varepsilon_{p l}\right)_{i}$ : uniaxial incremental free expansion strain of cement paste; uniaxial incremental restrained expansion strain of concrete under an internal restraint; uniaxial incremental elastic strain of concrete, and incremental plastic strain of concrete at any $i$-th time interval during of the analyzed curing period, respectively.

The algebraic sum of concrete elastic and plastic incremental strains at any $i$-th time interval by the theory of aging viscoelasticity can be expressed as [2]:

$$
\left(\Delta \varepsilon_{e l}\right)_{i}+\left(\Delta \varepsilon_{p l}\right)_{i}=J_{c}\left(\tau_{i}, \tau_{i-1 / 2}\right) \cdot\left(\Delta \sigma_{i r}\right)_{i}+\sum_{j=1}^{i-1}\left(J_{c}\left(\tau_{i}, \tau_{j-1 / 2}\right)-J_{c}\left(\tau_{i-1}, \tau_{j-1 / 2}\right)\right) \cdot\left(\Delta \sigma_{i r}\right)_{j}
$$

where, $\left(\Delta \sigma_{i r}\right)_{i}$ : incremental self-stress under an internal restraint at any $i$-th time interval; $J_{\tilde{n}}\left(\tau_{i}, \tau_{i-1 / 2}\right)$ : uniaxial creep compliance function at time $\tau_{i}$ caused by a unit constant uniaxial stress that has been acting since time $\tau_{i-1 / 2} ; \tau_{i}$ and $\tau_{i-1 / 2}$ : end and middle of any $i$-th time interval.

The incremental restrained expansion strain of concrete under an internal restraint and incremental free expansion strain of cement paste at any $i$-th time interval can be expressed by the following equations:

$$
\left(\Delta \varepsilon_{\tilde{n} p}\right)_{i}=\varepsilon_{\tilde{n} p}\left(\tau_{i}\right)-\varepsilon_{\tilde{n} p}\left(\tau_{i-1}\right) ; \quad\left(\Delta \varepsilon_{i r}\right)_{i}=\varepsilon_{i r}\left(\tau_{i}\right)-\varepsilon_{i r}\left(\tau_{i-1}\right)
$$

where, $\tau_{i-1}$ : start of any $i$-th time interval.

For calculation of the free expansion strain of cement paste $\left(\varepsilon_{\tilde{n} p}\right)$ the following expressions can be accepted:

$$
\varepsilon_{\tilde{n} p}\left(\tau_{i}\right)=\varepsilon_{\tilde{n} p}\left(\tau_{n}\right) \cdot \beta_{\varepsilon}\left(\tau_{i}\right) ; \beta_{\varepsilon}\left(\tau_{i}\right)=\exp \left(r \cdot\left(1-\left(\frac{\tau_{n}-\tau_{0}}{\tau_{i}-\tau_{0}}\right)^{0,5}\right)\right)
$$

where, $\varepsilon_{\tilde{n} p}\left(\tau_{n}\right)$ : free expansion strain of the cement paste at the end of analyzed curing time $\left(\tau_{n}\right) ; \beta_{\varepsilon}$ : coefficient to describe the development of free expansion strain of cement paste with time; 
$r$ coefficient that takes into account rate of the expansion process of cement paste; $\tau_{0}$ : parameter that takes into account the percolation threshold of the cement paste.

The restrained expansion strain of concrete under an internal restraint $\left(\varepsilon_{i r}\right)$ is calculated from the general solution presented in [3] for a three-phase composite model including an effective spherical inclusion from aggregate and an interfacial transition zone (ITZ), a shell of cement paste located around it, and an effective homogeneous medium:

$$
\varepsilon_{i r}\left(\tau_{i}\right)=\frac{K_{\tilde{a} p} \cdot \varepsilon(\tau) \cdot\left(1_{n c} V\right) \cdot\left(3_{i n c} K+{ }_{c p}^{4} \cdot G\right)}{K_{c p} \cdot\left(3 \cdot K_{i n c}+4 \cdot G_{c p}\right)-4 \cdot V_{i n c} \cdot G_{c p} \cdot\left(K_{c p}-K_{i n c}\right)}
$$

where, $K_{\text {inc }}$ : bulk modulus of the effective spherical inclusion from aggregate and an interfacial transition zone; $K_{c p}$ and $G_{c p}$ : bulk modulus and shear modulus of the cement paste, respectively; $V_{i n c}$ : relative volume content of the effective spherical inclusion from aggregate and an interfacial transition zone by volume of concrete.

Substituting Eq. (3) into Eq. (2) the following equation for calculating of the incremental self-stress under an internal restraint at any i-th time interval can be expressed:

$$
\left(\Delta \sigma_{i r}\right)_{i}=\frac{\left(\Delta \varepsilon_{\tilde{n} p}\right)_{i}-\left(\Delta \varepsilon_{i r}\right)_{i}-\sum_{j=1}^{i-1}\left[\left(J_{c}\left(\tau_{i}, \tau_{j-1 / 2}\right)-J_{c}\left(\tau_{i-1}, \tau_{j-1 / 2}\right)\right) \cdot\left(\Delta \sigma_{i r}\right)_{j}\right]}{J_{c}\left(\tau_{i}, \tau_{i-1 / 2}\right)}
$$

The restrained expansion strain of concrete under an internal restraint $\left(\varepsilon_{r e, i r}\right)$ is calculated as an algebraic sum of the incremental restrained expansion strain at each i-th time interval during the analyzed curing period $i \in[1, n]$ taking into account a cumulative force induced by the internal restraint is determined as an algebraic sum of incremental self-stresses under an internal restraint at time intervals $j \in[1, n-1]$ :

$$
\varepsilon_{r e, i r}=\sum_{i=1}^{n}\left(\Delta \varepsilon_{i r}\right)_{i}-\frac{\sum_{j=1}^{n-1}\left(\Delta \sigma_{i r}\right)_{j}}{E_{c}\left(\tau_{n-1}\right)}
$$


where, $E_{c}\left(\tau_{n-1}\right)$ : Young's modulus of the expansive concrete at the start of $n$-th time interval; $n$ : time intervals during the analyzed curing period.

$$
\underline{\sum_{j=1}^{n-1}\left(\Delta \sigma_{i r}\right)_{j}}
$$

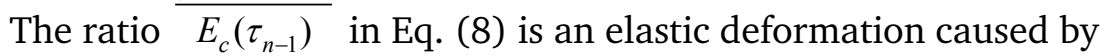
stress field in the concrete due total response of the internal restraint (aggregate).

Based on Eq. (2) and Eq. (3) the incremental restrained expansion strain of concrete under an external restraint at any $i$-th time interval can be expressed by the following equation:

$$
\left(\Delta \varepsilon_{e r}\right)_{i}=\left(\Delta \varepsilon_{r e, i r}\right)_{i}-J_{c}\left(\tau_{i}, \tau_{i-1 / 2}\right) \cdot\left(\Delta \sigma_{e r}\right)_{i}-\sum_{j=1}^{i-1}\left[\left(J_{c}\left(\tau_{i}, \tau_{j-1 / 2}\right)-J_{c}\left(\tau_{i-1}, \tau_{j-1 / 2}\right)\right) \cdot\left(\Delta \sigma_{e r}\right)_{j}\right]
$$

where, $\left(\Delta \varepsilon_{e r}\right)_{i}$ : radial incremental restrained expansion strain of concrete under an external restraint at any $i$-th time interval during the analyzed curing period; $\left(\Delta \sigma_{e r}\right)_{i}:$ incremental self-stress under an external restraint at any $i$-th time interval.

Finally, restrained expansion strain of concrete core in the CFST structures $\left(\varepsilon_{r e}\right)$ is calculated by the following equation:

$$
\varepsilon_{r e}=\sum_{i=1}^{n}\left(\Delta \varepsilon_{e r}\right)_{i}-\frac{\sum_{j=1}^{n-1}\left(\Delta \sigma_{e r}\right)_{j}}{E_{c}\left(\tau_{n-1}\right)}
$$

$$
\sum_{j=1}^{n-1}\left(\Delta \sigma_{e r}\right)_{j}
$$

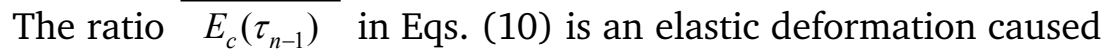
stress field in the concrete due total response of the external restraint (steel shell).

The incremental self-stress under an external restraint at any i-th time interval is calculated in accordance with the equilibrium condition of forces in the concrete core and steel tube as:

$$
\left(\Delta \sigma_{e r}\right)_{i}=\frac{\delta_{s}}{R_{c}} \cdot E_{s} \cdot\left(\Delta \varepsilon_{e r}\right)_{i},
$$


where, $E_{s}$ :Young's modulus of steel; $\delta_{s}$ and $R_{c}$ : thicknesses of wall of the steel tube and radius of the concrete core, respectively.

\section{Model parameters}

In the considered model uniaxial creep compliance function $J_{\tilde{n}}\left(\tau_{i}, \tau_{j-1 / 2}\right)$ is accepted in the form in accordance with [4]:

$$
J_{\tilde{n}}\left(\tau_{i}, \tau_{j-1 / 2}\right)=\frac{1}{E_{\tilde{n}}\left(\tau_{i-1 / 2}\right)}+\frac{\varphi\left(\tau_{i}, \tau_{j-1 / 2}\right)}{E_{\tilde{n}, 28}}
$$

where, $E_{\tilde{n}}\left(\tau_{i-1 / 2}\right)$ and $E_{\tilde{n}, 28}$ : Young's modulus of expansive concrete at time $\tau_{i-1 / 2}$ and at 28 days, respectively; $\varphi\left(\tau_{i}, \tau_{j-1 / 2}\right):$ creep coefficient of expansive concrete at time $\tau_{i}$ caused by a unit constant uniaxial stress that has been acting since time $\tau_{j-1 / 2}$, is calculated by the following equation [4]:

$$
\varphi\left(\tau_{i}, \tau_{j-1 / 2}\right)=\varphi_{0} \cdot f_{\varphi}\left(\tau_{i}, \tau_{j-1 / 2}\right)
$$

where, $\varphi_{0}$ : notional creep coefficient that in the considered model is calculated by the expression suggested in [5]:

$$
\varphi_{0}=5,31 \cdot\left(\frac{E\left(\tau_{j-1 / 2}\right)}{E_{\tilde{n}, 28}}-1\right)^{2}+1,11
$$

The coefficient describing the development of creep with time after loading $f_{\varphi}\left(\tau_{i}, \tau_{i-1 / 2}\right)$ is calculated in accordance with [5]:

$$
f_{\varphi}\left(\tau_{i}, \tau_{j-1 / 2}\right)=\left(\frac{\left(\tau_{i}-\tau_{j-1 / 2}\right)}{\beta_{h}+\left(\tau_{i}-\tau_{j-1 / 2}\right)}\right)^{0,3}
$$

where, $\beta_{h}$ : the coefficient representing the effect of loading age on rate of creep development is calculated by the expression suggested in [5]:

$$
\beta_{h}=\left\{\begin{array}{l}
0,000001,0 \leq \frac{E\left(\tau_{i}\right)}{E_{\tilde{n}, 28}}<0,346 \\
40,5 \cdot\left(\frac{E\left(\tau_{i}\right)}{E_{\tilde{i}, 28}}-0,346\right)+0,485, \frac{E\left(\tau_{i}\right)}{E_{, 28}} \geq 0,346
\end{array}\right.
$$


To calculate the Young's modulus of the cement paste, the following equations is accepted:

$$
E_{\text {ipp }}\left(\tau_{i}\right)=E_{\text {ip }}\left(\tau_{n}\right) \cdot \beta_{E}\left(\tau_{i}\right) ; \beta_{E}\left(\tau_{i}\right)=\exp \left(s \cdot\left(1-\left(\frac{\tau_{n}-\tau_{0}}{\tau_{i}-\tau_{0}}\right)^{0,5}\right)\right)
$$

where, $E_{i p}\left(\tau_{n}\right)$ : Young's modulus of the cement paste at the end of analyzed curing period; $\beta_{E}$ : the coefficient which describes the development of Young's modulus of concrete with time; $s$ : coefficient which depends on the strength class of cement.

The bulk modulus and shear modulus of the cement paste is calculated by the standard conversion formulae:

$$
K_{c p}=\frac{E_{c p}}{3 \cdot\left(1-2 \cdot v_{c p}\right)} ; \quad G_{c p}=\frac{E_{c p}}{2 \cdot\left(1+v_{c p}\right)}
$$

where, $v_{c p}$ : Poisson's ratio of the cement paste.

The relative volume content of the effective spherical inclusion $V_{i n c}$ is calculated in accordance with [6]:

$$
V_{\text {inc }}=V_{a} \cdot \sum_{j} f_{a, j} \cdot\left(\frac{b_{a, j}}{a_{a, j}}\right)^{3}
$$

where, $v_{a}$ : relative aggregate content by volume of concrete; $f_{a, j}$ : volume fraction of $j$-th kind of aggregate particle fraction that is given by a sieve analyses $\left(j \in\left[1, n_{a}\right], n_{a}\right.$ : total of aggregate particle fractions); $a_{a, j}$ and $b_{a, j}$ : radius of $j$-th kind of aggregate particles that is given and radius of $j$-th kind of effective spherical inclusion, that is calculated by the following equations:

$$
a_{a, j}=E\left[a_{a, j}\right] ; b_{a, j}=a_{a, j}+\delta_{i t z}
$$

where, $E\left[a_{a, j}\right]$ : expected (mean) value of radius $j$-th kind of aggregate particles that is calculated by the equations suggested in [7]; $\delta_{i t z}$ : thickness of interfacial transition zone. 
To determine the bulk modulus of the effective spherical inclusion Generalized Self-Consistent Scheme is used [8] by a step-by-step homogenization technique, in which at the $\mathrm{i}$-th iteration $\left(i \in\left[1, n_{a}\right]\right)$ is calculated the bulk modulus of $j$-th kind of effective spherical inclusion, using the bulk modulus of effective spherical inclusion calculated at the (i-1)-th iteration:

$$
\left\{\begin{array}{l}
\left(K_{\text {inc }}\right)_{i}=\left(K_{\text {inc }}\right)_{i-1}+\frac{f_{a, j}^{\prime} \cdot\left[K_{a, j}-\left(K_{\text {inc }}\right)_{i-1}\right]}{1+\left(1-f_{a, j}^{\prime}\right) \cdot\left[\frac{K_{a, j}-\left(K_{\text {inc }}\right)_{i-1}}{\left(K_{\text {inc }}\right)_{i-1}+\frac{4}{3} \cdot\left(G_{\text {inc }}\right)_{i-1}}\right]}, \text { if } i \geq 1 \\
\left(K_{\text {inc }}\right)_{0}=K_{\text {izz }}
\end{array}\right.
$$

where, $K_{a, j}$ : bulk modulus of $j$-th kind of aggregate particles; $K_{i t z}$ : bulk modulus of interfacial transition zone, that is calculated as $K_{i t z}=\frac{1}{3} \cdot K_{c p} ;\left(K_{i n c}\right)_{i}$ and $\left(G_{i n c}\right)_{i}$ : bulk modulus and shear modulus of the effective spherical inclusion from aggregate and an interfacial transition zone at the $i$-th iteration; $f_{a, j}^{\prime}$ : volume fraction of $j$-th kind of aggregate particles by volume $j$-th kind of effective spherical inclusion, that is calculated as $f_{a, j}^{\prime}=\left(\frac{a_{a, j}}{b_{a, j}}\right)^{3}$.

The effect of elevated or reduced temperatures during the analyzed curing time may be taken into account by adjusting the concrete age:

$$
\tau_{i, e}=\sum_{j=1}^{i}\left[\Delta \tau_{j} \cdot\left(\exp \left[\frac{E_{a}}{R} \cdot\left(\frac{1}{T_{j}}-\frac{1}{T_{0}}\right)\right]\right)\right]
$$

where, $\tau_{i, e}$ : temperature adjusted concrete age which replaces $\tau_{i}$ in the corresponding equations; $\Delta \tau_{j}:$ number of days where a temperature $T_{j}$ prevails; $T_{0}$ : mean concrete temperature of $20^{\circ} \mathrm{C} ; E_{a}$ : activation energy of the expansive binder. 


\section{NUMERICAL SIMULATION OF THE RESTRAINED EXPANSION STRAINS AND SELF-STRESSES OF EXPANSIVE CONCRETE CORE ACCORDING TO THE PROPOSED MODEL}

\section{Input data}

For the numerical simulation of the proposed stress-strain development model, the data presented in the Tables 1-2 were accepted. The expansive concrete mix composition, free expansion strain of the expansive binder (for specimen series CE-6) and expansion strain of concrete on the unrestrained condition (for specimen series II-PEC-0) were taken in accordance with [3].

The analyzed curing time is 28 days. The temperature conditions during the analyzed curing time is $20^{\circ} \mathrm{C}$.

Table 1

\section{Characteristics of the materials used in simulations}

\begin{tabular}{|c|c|c|c|}
\hline 1. Expansive binder content* $\mathrm{kg} / \mathrm{m}^{3}$ & \multicolumn{3}{|c|}{600} \\
\hline 2. Water content, $\mathrm{kg} / \mathrm{m}^{3}$ & \multicolumn{3}{|c|}{240} \\
\hline 3. Fine aggregate content, $\mathrm{kg} / \mathrm{m}^{3}$ & \multicolumn{3}{|c|}{600} \\
\hline 4. Coarse aggregate content, $\mathrm{kg} / \mathrm{m}^{3}$ & \multicolumn{3}{|c|}{960} \\
\hline 5. Water/Binder ratio & \multicolumn{3}{|c|}{0,4} \\
\hline 6. Density of expansive binder, $\mathrm{kg} / \mathrm{m}^{3}$ & \multicolumn{3}{|c|}{3000} \\
\hline 7. Density of fine aggregate, $\mathrm{kg} / \mathrm{m}^{3}$ & \multicolumn{3}{|c|}{2630} \\
\hline 8. Density of coarse aggregate, $\mathrm{kg} / \mathrm{m}^{3}$ & \multicolumn{3}{|c|}{2670} \\
\hline 9. Young's modulus of fine aggregate, $\mathrm{GPa}$ & \multicolumn{3}{|c|}{56} \\
\hline 10. Young's of coarse aggregate, $\mathrm{GPa}$ & \multicolumn{3}{|c|}{60} \\
\hline 11. Young's modulus of steel, GPa & \multicolumn{3}{|c|}{200} \\
\hline 12. Young's modulus of cement paste at the 28 days age, GPa & \multicolumn{3}{|c|}{25} \\
\hline 13. Free expansion strain of cement paste at the 28 days age, $\%$ & \multicolumn{3}{|c|}{2,63} \\
\hline 14. Poisson's ratio of aggregates & \multicolumn{3}{|c|}{0,23} \\
\hline 15. Poisson's ratio of steel & \multicolumn{3}{|c|}{0,25} \\
\hline 16. Poisson's ratio of cement paste & \multicolumn{3}{|c|}{0,2} \\
\hline 17. Thickness of interfacial transition zone, $\mu \mathrm{m}$ & \multicolumn{3}{|c|}{50} \\
\hline 18. Value $r$ & \multicolumn{3}{|c|}{0,11} \\
\hline 19. Value $\tau_{0}$, day & \multicolumn{3}{|c|}{0,14} \\
\hline 20. Value $s$ & \multicolumn{3}{|c|}{0,11} \\
\hline 21. Thicknesses of the steel tube, $\mathrm{mm}$ & 2,5 & 3,5 & 6 \\
\hline 22. Outer diameter of the steel tube, $\mathrm{mm}$ & 50 & 102 & 203 \\
\hline
\end{tabular}


Characteristics of fine and coarse aggregate

\begin{tabular}{|c|c|c|c|c|c|c|c|c|c|c|}
\hline \multicolumn{10}{|c|}{ Fine aggregate } & \multicolumn{7}{|c|}{ Coarse aggregate } \\
\hline \multicolumn{10}{|c|}{ Percentage retained on each sieve* } \\
\hline \multicolumn{10}{|c|}{ Sieve sizes, mm } \\
\hline 0,125 & 0,25 & 0,5 & 1 & 2 & 4 & 8 & 2 & 4 & 8 & 16 \\
\hline 5 & 10 & 20 & 30 & 25 & 8 & 0 & 16 & 24 & 60 & 0 \\
\hline \multicolumn{10}{|c|}{ *Percentage retained on pan: $2 \%$} \\
\hline
\end{tabular}

\section{Simulation results}

The main simulation results of the restrained expansion strains and self-stresses of expansive concrete core according to the proposed model are shown on the Figures 1-3.

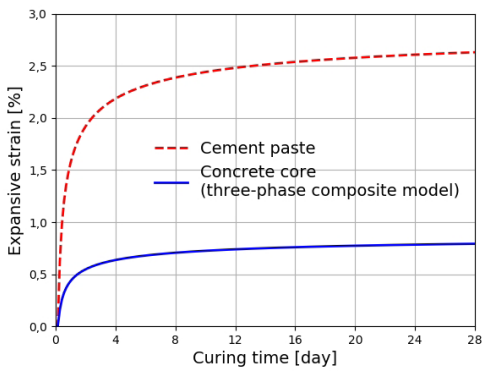

a)

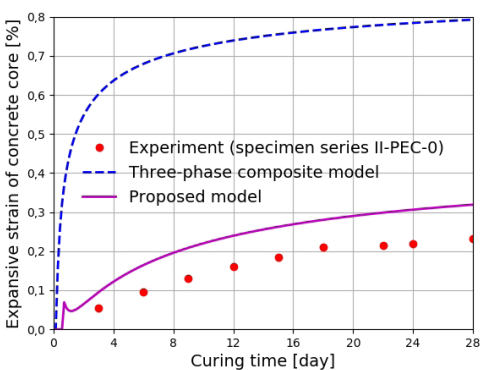

b)

Figure 1. Simulation results of expansive strain of cement paste (a) and expansive strain of concrete core $(a, b)$ in the absence of an external restraint

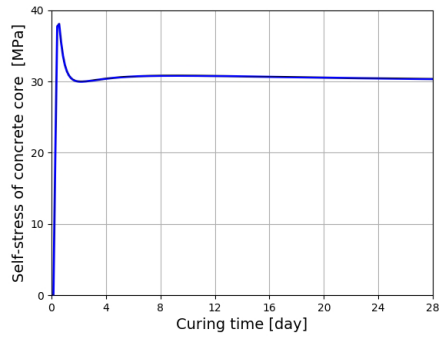

Figure 2. Simulation result of self-stress of concrete core in the absence of an external restraint 


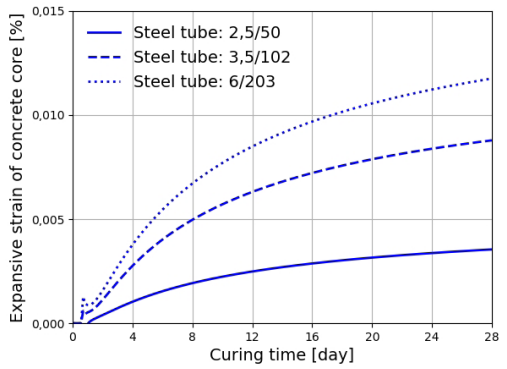

a)

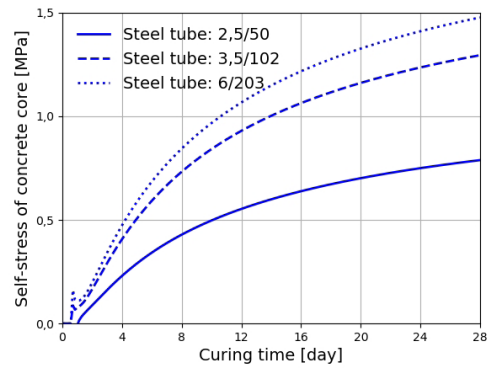

b)

Figure 3. Simulation results of expansive strain of concrete core (a) and self-stress of concrete core (b) in the round steel tube

\section{CONCLUSION}

Simulation results showed that the three-phase composite model based on the elasticity theory significantly over-estimate the expansion strains of concrete (Fig. 1), clearly indicating on the stress relaxation during development of expansion restrained strain, which must be considered to improve prediction accuracy of the expansion strains of concrete.

Therefore, it is reasonable to include aging viscoelastic effects in a restrained expansion strains model, that is primarily associated the viscoelastic behavior of CSH gel. In addition, as was presented in [1] the development of expansion strain under restrained conditions leads to induce a force by each restraint that should be considered as an additional restraint for the free expansion. In case of CFST structures, it should be considered that the expansion strains of concrete core develop as a result both internal (aggregates) and external (steel shell) restrained conditions. At this rate, more reasonable is the term «restrained expansion strains of concrete».

Presented the stress-strain development model for the restrained expansion strains and self-stresses values estimation take into account (a) stresses relaxation due develops of elastic and plastic strains under both restrained conditions (internal and external) and (b) a cumulative force induced by the restraint demonstrates well predict the restrained expansion strain of concrete under internal restrained conditions, validating the accepted assumptions. 
The results obtained by the proposed model can be used as input data for estimation of the stress-strain development in a steel shell of the round cross-section CFST structures which are filled of the expansive concrete.

\section{REFERENCES}

1. Semianiuk V., Tur V., Herradora M. F., Paredes M. G. (2017) Early age strains and self-stresses of expansive concrete members under uniaxial restraint conditions. Construction and Building Materials. 2017. Vol. 131. pp. 39-49.

2. Bažant Z. P., Najjar L. J. (1973) Comparison of Approximate Linear Methods for Concrete Creep. Journal of the Structural Division.1973. Vol. 99, iss. 9. pp. 1851-1874.

3. Xi Y., Jennings H. M. (1997) Shrinkage of cement paste and concrete modelled by a multiscale effective homogeneous theory. Materials and Structures. 1997. Vol. 30. pp. 329-339.

4. Walraven J. [et al.] The fib Model Code for Concrete Structures 2010. Wilhelm Ernst \& Sohn. 2013. 434 p.

5. Ito H., Maruyama I., Tanimura M., Sato R. (2004) Early Age Deformation and Resultant Induced Stress in Expansive High Strength Concrete. Journal of Advanced Concrete Technology. 2004. Vol. 2, iss. 2. pp. 155-174.

6. Garboczi E. J., Berryman J. G. (2001) Elastic moduli of a material containing composite inclusions: Effective medium theory and finite element computations. Mechanics of Materials. 2001. Vol. 33, iss. 8. pp. 455-470.

7. Garboczi E. J., Bentz D. P. (1998) Multi-scale analytical/numerical theory of the diffusivity of concrete. Advanced Cement Based Materials. 1998. Vol. 8, iss. 2. pp. 77-88.

8. Aboudi J., Arnold S. M., Bednarcyk B. A. Mechanics of Composite Materials. A Generalized Multiscale Analysis Approach. Butterworth-Heinemann. 2012. 984 p.

Received: 13.11.2019 